\title{
Argentina: Dissemination of genetically modified cotton and its impact on the profitability of small-scale farmers in the Chaco province
}

Valeria Arza, Laura Goldberg and Claudia Vázquez

ABSTRACT

KEYWORDS

JEL CLASSIFICATION

AUTHORS
This article analyses the adoption of genetically modified cotton by small-scale farmers in the Chaco region of Argentina. It uses the socio-technical configuration of the technology as a conceptual framework, which postulates the existence of a set of factors that significantly affect the way in which technologies operate. Based on this framework, the article describes the conditions under which small-scale farmers in the Chaco region adopt gm cotton; and it identifies the differences between them and large-scale farmers, on which most of the literature focuses. Qualitative methodologies are used to analyse the breaks and continuities in productive practices affecting the profitability of small-scale farmers since the introduction of gm cotton. It is found that the productive difficulties they face have remained essentially unchanged, and, in some cases, have become more accentuated.
Cotton, crops, genetically modified organisms, small farms, productivity, income, economic conditions, Argentina

O13, O33, Q16

\footnotetext{
Valeria Arza is a Research Fellow at the National Council for Scientific and Technical Research (conicEt) and at the Research Centre for Transformation (CENIT). varza@fund-cenit.org.ar

Laura Goldberg is a Research Fellow at the Research Centre for Transformation (cENIT). lgoldberg@fund-cenit.org.ar

Claudia Vázquez is a Research Fellow at the Research Centre for Transformation (cENIT). claudiavazquez@fund-cenit.org.ar
} 


\section{I}

\section{Introduction}

Since their launch in Argentina in 1996, genetically modified (GM) crops have spread very rapidly with adoption rates among the highest in the world. GM cotton was introduced in 1998, and by 2010 nearly all of the areas sown with this crop were cultivating transgenic varieties. Although the speed of its dissemination may reflect the benefits that GM technology brings to its users, this article finds that the benefits have not been equal for everyone: transgenic varieties were better suited to the production conditions of large-scale farmers.

The key contribution to profitability made by GM cotton stems from cost savings in labour and pesticides. However, small-scale farmers do not benefit from that saving as large-scale farmers do, because they do not hire labour or use pesticides to the same extent. Moreover, the main pest currently afflicting the region, the boll weevil, is not one of the insects controlled by available GM seeds. As will be argued in this article, the introduction of GM crops may have actually aggravated other socio-productive problems faced by small-scale farmers, related to their disadvantaged position in the marketing chain.

In fact, many small-scale farmers have abandoned cotton growing over the last few years, and some have even sold their land. Some provincial technical experts and workers believe cotton production is no longer viable for small-scale farmers in the Chaco. Although this situation may have started to develop before the introduction of GM technology, which is consistent with the expansion of the "productivist" paradigm that attempts to generate and exploit economies of scale (Vanloqueren and Baret, 2009), ${ }^{1}$ this article propounds the view that the adoption of that technology has widened

\footnotetext{
$\square$ This study received financial support from the International Development Research Centre (IDRC), Ottawa, Canada, and from the National Council for Scientific and Technical Research (CONICET), project PIP112-200801-02758, Argentina. The authors are grateful to staff at the Office of the Under-Secretariat for Rural Development and Family Farming of the Government of Chaco province, researchers and extension workers at the National Institute for Agricultural Technology (INTA) and representatives of the rural consortia in the localities visited, for all the assistance provided during the fieldwork. We are also grateful for comments received from an anonymous referee of the cepal Review.

1 The productivist paradigm has been a significant element on the national agriculture agenda in Argentina since the 1970s. See for example, Becerra, Baldatti and Pedace (1997) and Gárgano (2011).
}

the gap between large- and small-scale farmers, thereby fuelling the perception that small-scale cotton-growing is no longer viable.

Most studies of the effect of GM crops in Argentina view the technology as an artifact. In other words, they focus on the virtues of GM seeds and their associated technological package (Qaim and de Janvry, 2003 and 2005; Trigo and Cap, 2006; Trigo and others, 2002; Trigo, Falck-Zepeda and Falconi, 2010); and they evaluate the effectiveness of seeds that are insect-resistant and herbicide-tolerant (how much pesticide or labour they save) and the economic effects in terms of changes in yields and profitability.

Within this group, the specific literature on GM cotton in Argentina concludes that its adoption, particularly in the case of seeds resistant to lepidoptera insects, has increased yields thanks to better pest management (Qaim and de Janvry, 2005; Trigo and Cap, 2006). These studies do not consider small-scale farmers, but are based either on information from surveys of relatively large-scale farmers, or on aggregate modelling exercises for farmers as a whole. Moreover, as these studies attribute to the artifact all of the virtues that the technology can produce, there is no in-depth analysis of differences in the contexts in which it is adopted by different users. For example, it is assumed that GM seeds were generally adopted as part of a package including good agronomy practices, specific inputs and modern machinery. Nonetheless, while large-scale farmers generally gain access to the full technological package, smaller-scale farmers generally use an incomplete package that consists of uncertified and low-quality GM seeds, with haphazard herbicide use.

This article takes a broader view of the technologies, understanding them as "socio-technical configurations, rather than individual artifacts (seeds, machines, and other items). The socio-technical-configuration concept was developed in the fields of sociology and the economics of science and technology (Bijker, 1995; Klein and Kleinman, 2002; Kleinman, 1995; Pinch, 1996; Pinch and Bijker 1987; Rosen, 1993; Williams and Edge, 1996) and argue that technologies need to be understood in relation to the contexts in which they are produced, marketed and adopted.

Under this approach, the artifact itself is just one aspect of a socio-technical configuration, which also includes social, cultural, political and economic 
dimensions. With regard to these, this article focuses on the users' capacities and practices, and on their bargaining power in relation to other key players in the productive chain. The socio-technical approach argues that the artifact will "work" differently in different socio-technical configurations. This approach makes it possible to appreciate the flexibility of the technologies: when the social context changes, the technologies have different effects, consequences and meanings.

This article shows that the socio-technical configuration of GM cotton differs greatly between small- and large-scale farmers. Accordingly, although the existing literature concludes that the introduction of GM technology unequivocally increased the profitability of cotton production, this article puts that conclusion in a more relative light, and claims that in Chaco province the effects were not the same for all farmers. The study's main finding is that GM technology, in the case of cotton in Chaco province, has had different economic effects for large- and small-scale farmers, and has widened inequalities between them.

The empirical evidence reviewed here was obtained in participatory workshops with small-scale cotton farmers, held in July and September 2010 and in July 2011 in four cotton-growing localities in Chaco province (Pampa del Indio, Quitilipi, Villa Berthet and Sáenz Peña). About 20 people participated in each workshop, mainly small-scale farmers (cultivating less than 10 ha) but also some medium-sized farmers (areas of up to 100 ha), together with intermediaries, extension workers from the National Institute of Agricultural Technology (INTA) and local officials. The workshops, lasting roughly a day and a half each, were organized using participatory methodologies and aimed to identify productive practices, problems and potential solutions. The information collected during the workshop was complemented by in-depth interviews ${ }^{2}$ with INTA agents (8), government representatives (1), representatives of farmer co-operatives (2), leading members of farmers' organizations (2) and representatives of the seed industry (2).

This article is organized in three sections following this introduction. Section II focuses on the context in which GM cotton was adopted. It describes the historical evolution of cotton production and gives details of the main characteristics of the productive practices used by large- and small-scale farmers. Section III analyses the changes in productive practices that occurred following the dissemination of GM seeds, based on qualitative data obtained in the workshops. It firstly considers changes in yields, and then changes in profitability. Lastly, section IV sets out the conclusions and proposes policy guidelines.

\footnotetext{
2 The figures refer to the number of interview sessions organized, rather than the number of people actually interviewed, because in
} some sessions several people were interviewed.

\section{II}

\section{Cotton production in Argentina and the} practices of small-scale farmers in Chaco

\section{Main characteristics of cotton production}

Chaco province accounts for $60 \%$ of the total area in Argentina sown with cotton (see figure 1$){ }^{3}$ It is one of the country's poorest provinces: in 2009, the United Nations' human development index ranked it as Argentina's third poorest province. According to 2002 data (the latest national agricultural census with figures available) there were 18,000 cotton workers in the province, of whom

3 On average for the period 1969-2010, the Chaco produced $62 \%$ of the country's total cotton output (Ministry of Agriculture, Argentina).
13,000 were family workers (Valenzuela and Scavo, 2009). As seen in table 1 , a small proportion of largescale farmers accounted for half of the total area sown with cotton, while most farmers $(60 \%)$ were cultivating land plots smaller than 10 ha. Subsection 2 describes the chief characteristics of these two groups in detail.

Cotton production in Chaco began in the early twentieth century and has experienced major fluctuations through time, mainly reflecting changes in national policy and international prices. As tends to happen with commodities, production and price trends are correlated (see figure 2).

Since the late 1990s, the expansion of soya production has substantially displaced cotton-growing in 
TABLE 1

Chaco province: distribution of cotton farmers by size, 2002

\begin{tabular}{lccc}
\hline Size & Area in hectares & Percentage of farmers & Area sown with cotton (percentage) \\
\hline Minifundista & 0.1 to 10 & 60 & 9 \\
Small-medium & 10 to 100 & 34 & 41 \\
Large & Over 100 & 6 & 50 \\
\hline
\end{tabular}

Source: National Institute of Statistics and Censuses (INDEC), National Agricultural Census 2002.

FIGURE 1

\section{Argentina and Chaco: Cotton production in tons}

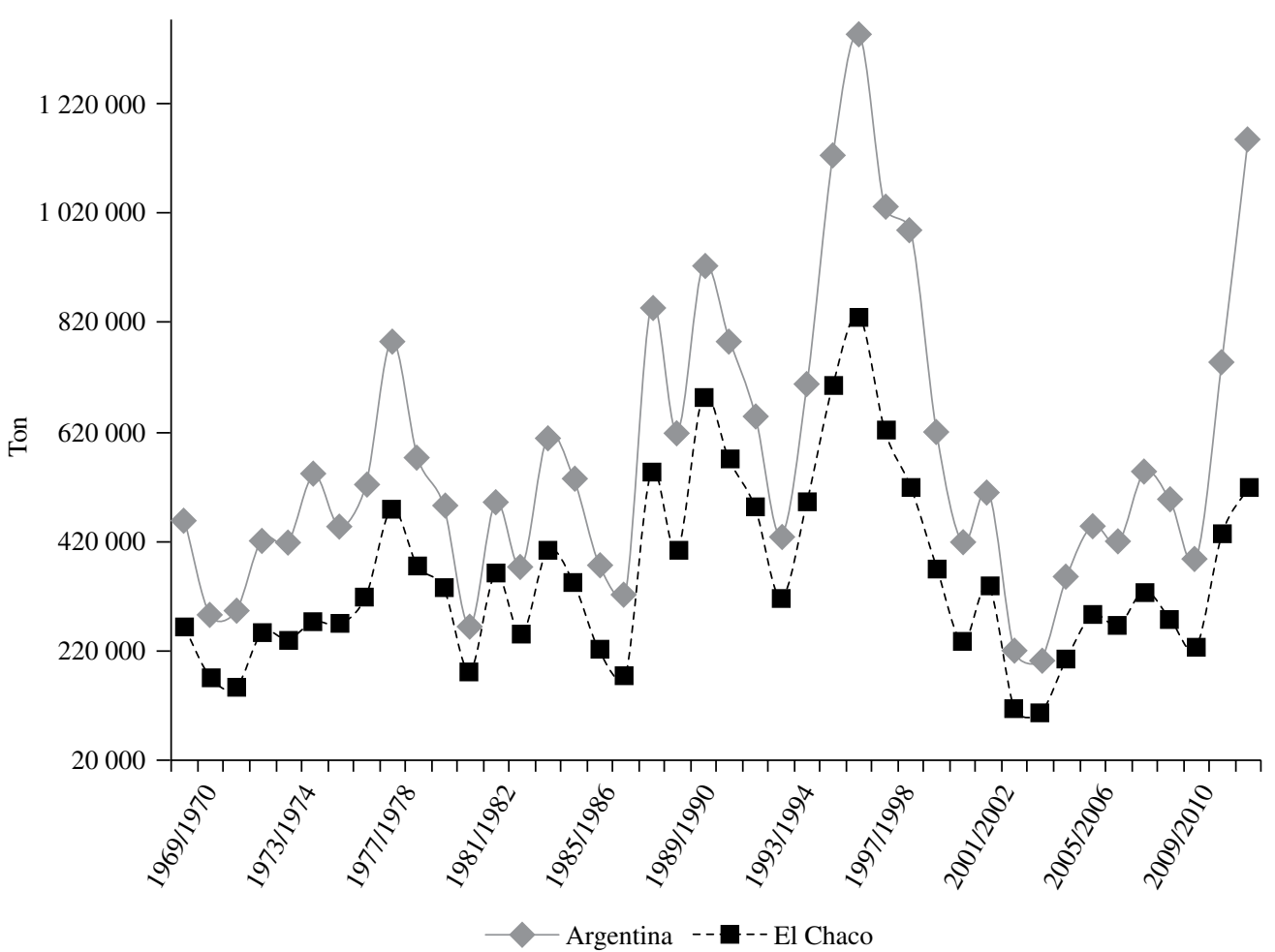

Source: prepared by the authors on the basis of the Integrated Agricultural Information System (SIIA) of the Ministry of Agriculture.

the province (see figure 3 ). With the economic recovery (particularly in the textile industry), cotton production revived as from 2003, but is still far below its historical levels (see figure 1).

Monsanto is the only firm to have introduced GM cotton seeds in Argentina, through its Genética Mandiyú joint-venture. This was created in 1997 between Monsanto, Delta \& Pine (subsequently taken over by Monsanto) and CIAGRO, the leading input distributor in the northeast of Argentina. In 1998, Monsanto obtained approval from the Ministry of Agriculture to market a variety of Bt cotton (resistant to lepidoptera insects), and in 2001 to market an RR seed tolerant to glyphosate (a broad- spectrum herbicide) whose genetic base comes from a variety originally developed by INTA (Guazuncho). Lastly, in 2009, they obtained commercial approval for two varieties that stack the Bt and RR genes of Monsanto (this combination of genes is known as the "Bt/RR stacked event"). In other words, seeds were obtained that are simultaneously lepidoptera resistant and glyphosate tolerant. One of them was marketed in that year, and the second was introduced commercially in 2011.

The introduction of transgenic cotton seeds transformed the cotton-seed market. Until the 1990s, the entire cotton-cultivation area was sown with varieties developed by INTA. The use of GM seeds, particularly 


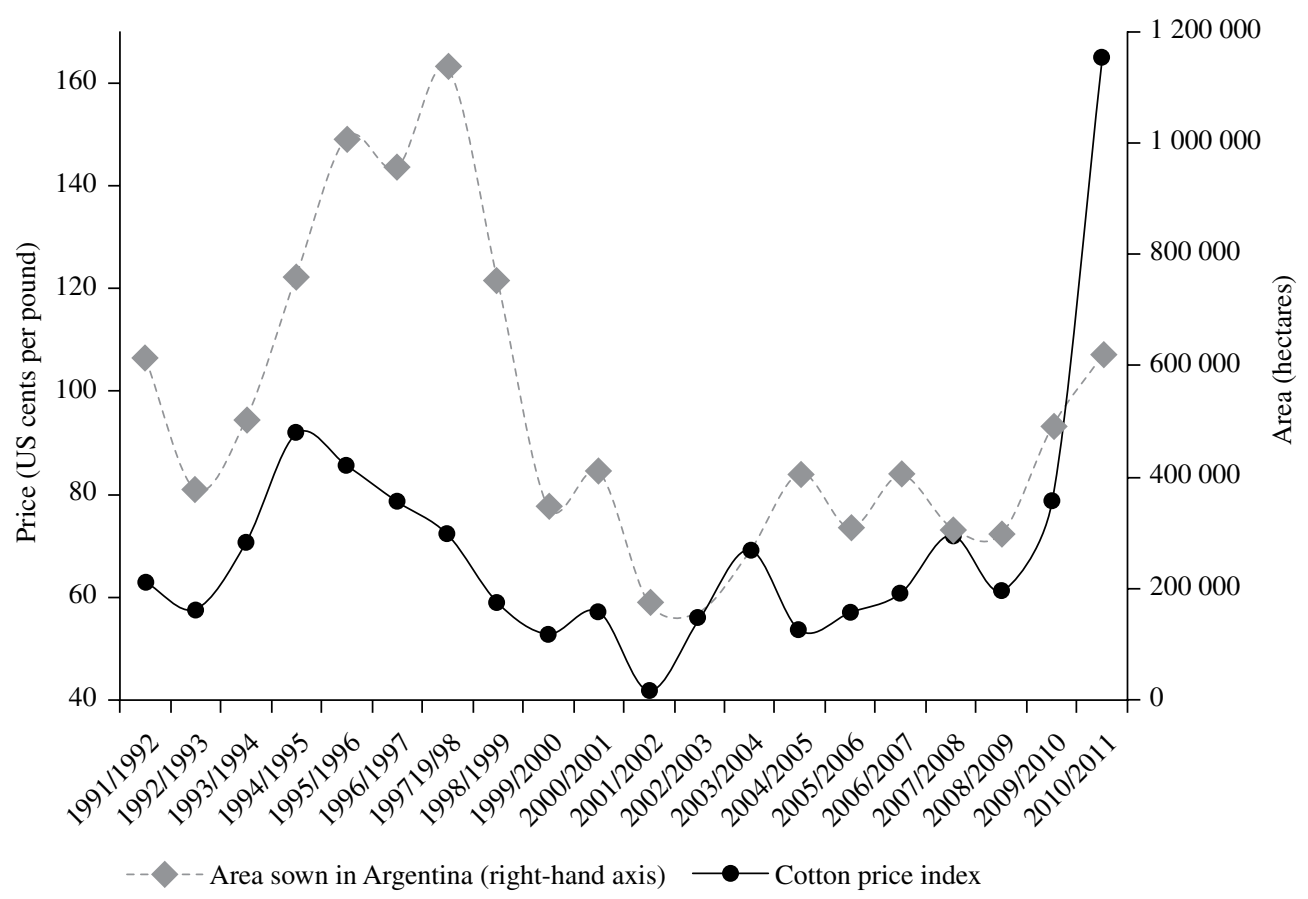

Source: prepared by the authors on the basis of the Integrated Agricultural Information System (SIIA) of the Ministry of Agriculture, for the area sown, and Cotlook Index "A" (http://www.cotlook.com/) for the price index (the international source most widely used for the cotton fibre export market).

herbicide-tolerant varieties and the stacked event, spread very fast (see figure 4); and, given its autogamous property (which allows self-fertilization) the seed could be multiplied informally, without authorization from Genética Mandiyú or quality control by the National Seed Institute (INASE). Industry sources report that uncertified GM cotton seeds, known as "white bag" seeds, accounted for over $80 \%$ of GM seeds sown in $2009 .{ }^{4}$

\section{Socio-technical configurations of cotton in the Chaco}

Small-scale farmers live in extremely precarious conditions, reflecting both the lack of access to basic housing services, electricity and water, and insufficient income. Most small-scale cotton-producing families live in shacks, ${ }^{5}$ in overcrowded conditions, and only some of them have very recently gained access to rural electrification. While they have no piped drinking water,

4 Interview held with industry representatives.

5 Very spartan rural dwellings with rough adobe walls, metal sheets, straw or similar products on the roof, and an earthen floor. they often also do not have a water well on their land. They work the land for their own subsistence; they feed themselves from the crops they grow in their vegetable garden and the animals that they breed in their farmstead ("chacra"). They usually find it hard to sell any surplus produce, because the markets in the towns are mostly far away. The only crop grown commercially is cotton. They use the income obtained from cotton sales to purchase basic goods, such as clothing and school utensils for their children. In most cases, the land is worked exclusively by the family. They receive support from local public programmes that provide soil preparation services, along with seeds and fuel. In addition, farmers generally receive some form of public transfer, which accounts for a large proportion of total household income. ${ }^{6}$ Formal credit is beyond their reach, and they use informal channels to purchase inputs on credit, paying a high interest rate. They also generally have fragile property rights over the

6 Since 2009, the various national income transfer programmes supporting families with children has been unified under the Universal Child Allowance for Social Protection (AUH), which pays \$220 per month for each child under 18 years of age, for up to five children; and $\$ 440$ for each disabled child with no age limit. 
FIGURE 3 Chaco province: trend of sown areas per crop (Hectares)

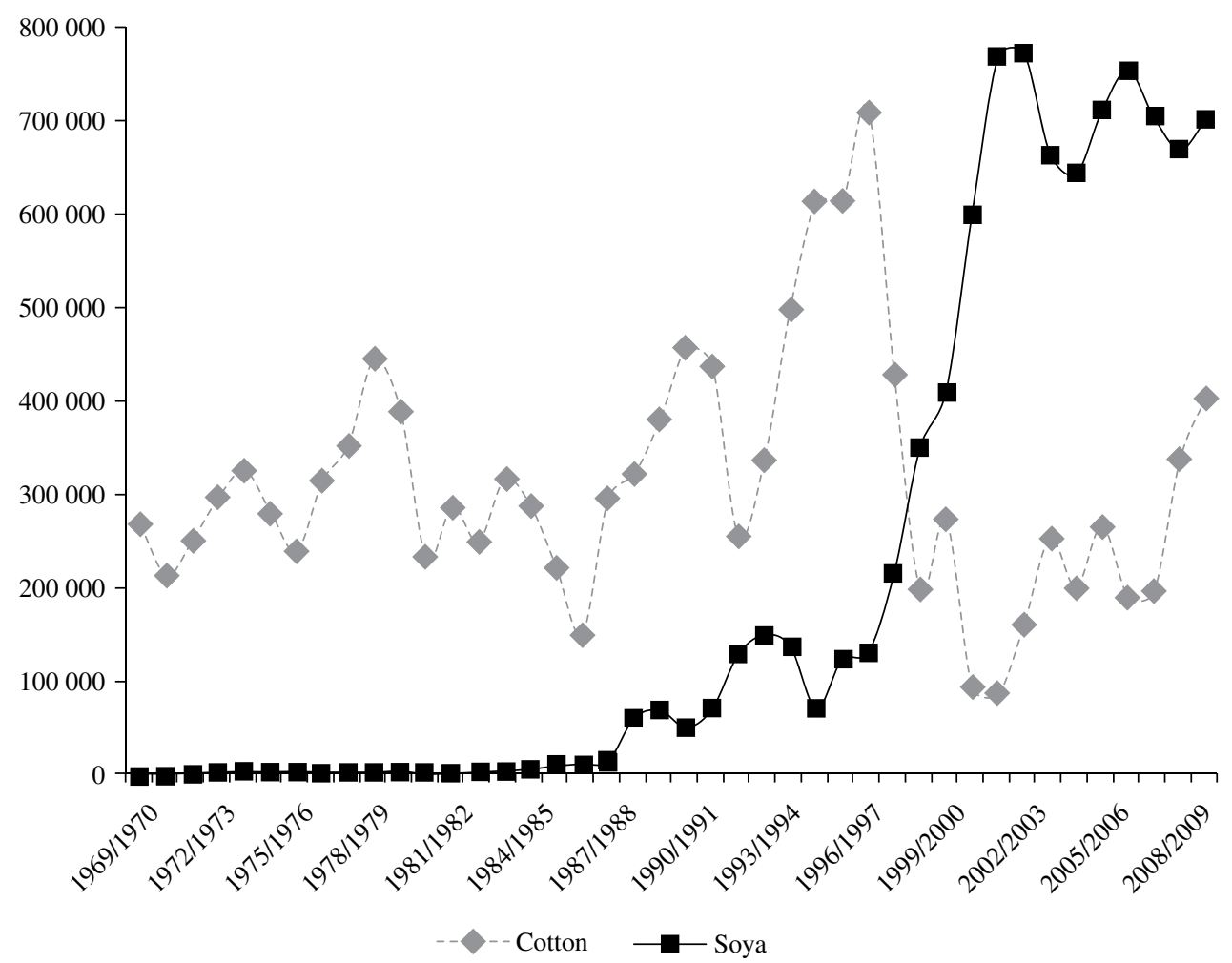

Source: prepared by the authors on the basis of the Integrated Agricultural Information System (SIIA) of the Ministry of Agriculture.

land on which they work and live, which makes them even more vulnerable.

In this context, small-scale cotton farmers in the Chaco face a serious productive and profitability problems. Yields are low mainly because they are severely affected by the boll weevil, a pest that is not controlled by transgenic technology. ${ }^{7}$ In addition, the soils they cultivate are degraded owing to deficient soil management practices (they do not practise crop rotation or use fertilizers). The technical assistance they receive is targeted on other crops and generally provided in the towns (in the form of informative meetings and other "office" activities) or else in demonstration fields, but not in the farmer's own chacra.

The low profitability of small-scale farmers is not only due to low yields, but also to their position in the

\footnotetext{
7 The boll weevil is a pest specific to the American continent, which feeds and reproduces in the cotton bolls, preventing flowering. Some scientific studies suggest that the spread of the pest could be related to the reduction in fumigation that occurred as a consequence of $\mathrm{Bt}$ (and $\mathrm{Bt} / \mathrm{RR}$ ) cotton (Grossi-de-Sa and others, 2007; CCIA, 2009).
}

marketing chain. The harvested cotton is sold raw and they have to accept the price offered by the intermediaries that collect it from the chacra. There are three reasons for this: (i) they are in debt to this intermediary, who is often the same person that provides them with credit for inputs, charging a high rate of interest; (ii) they face transport difficulties in reaching other markets; and (iii) they cannot sell their output in markets where tax registration is required, because they are not legally registered. ${ }^{8}$ This is compounded by the urgency of sale, because they need the income for family subsistence. In many cases, co-operatives operate as intermediaries, both as a buyers of the harvest and as suppliers of inputs,

\footnotetext{
${ }^{8}$ At the present time, to sell the harvest output directly to cooperatives or to entities that undertake the ginning process (see definition in footnote 9) requires tax registration, to be able to issue invoices. But small-scale farmers generally are not registered with the tax department, since it is very difficult for them to make regular contributions. Accordingly, they continue to sell raw cotton through informal channels to larger registered farmers or local warehouses, which then market it with the ginner.
} 


\section{Argentina: trend of area sown with gm cotton}

(Percentage of area sown with cotton)

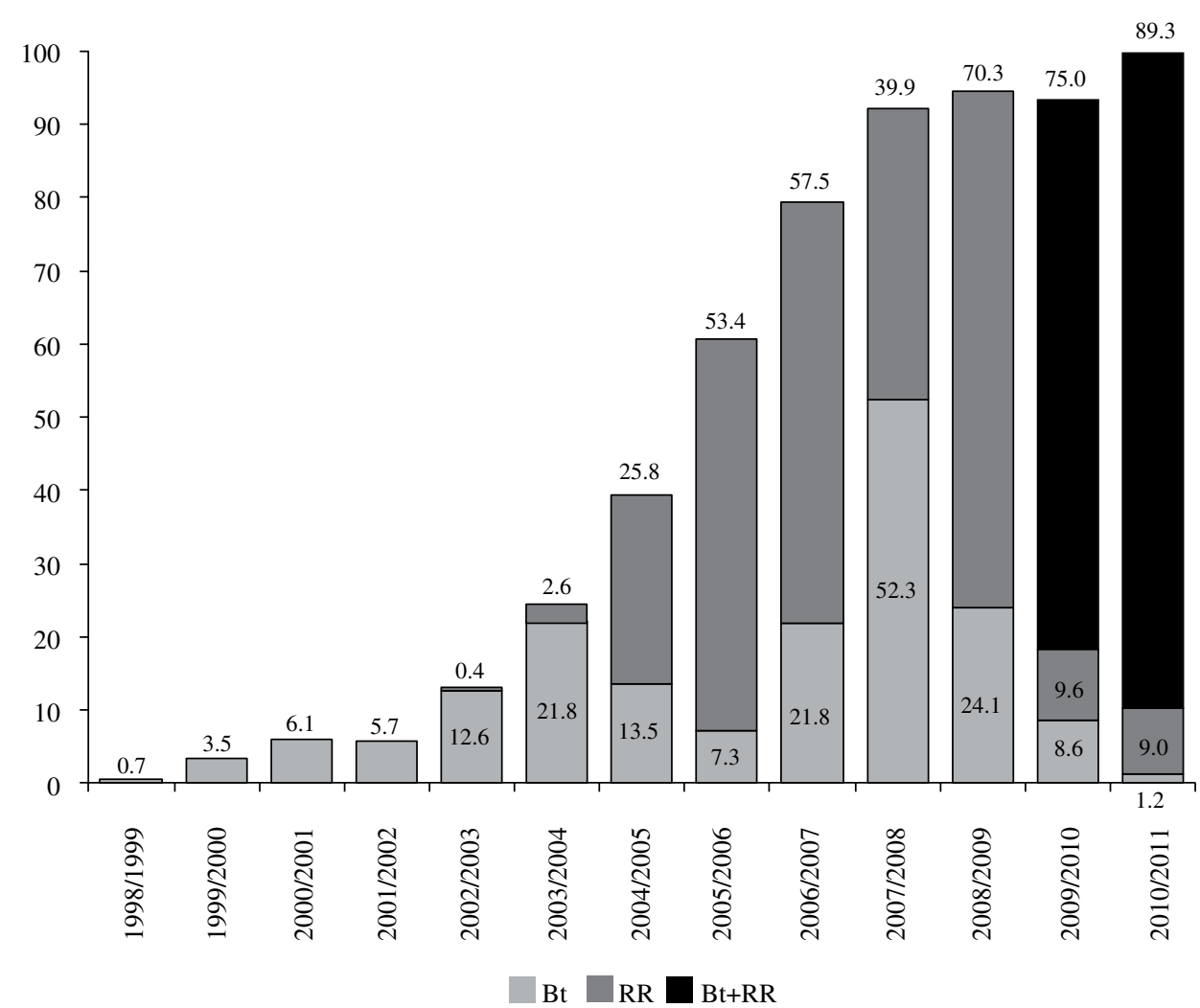

Source: prepared by the authors on the basis of the Integrated Agricultural Information System (SIIA) of the Ministry of Agriculture, for the total area sown, and the Argentine Council for Biotechnology Information and Development (ArgenBio) for the adoption of GM cotton by type.

Bt: Cotton variety resistant to lepidoptera insects.

RR: Cotton variety tolerant to herbicide, whose germplasm comes from a variety originally developed by INTA.

particularly seeds, because these are usually recovered in the "ginning" 9 process and sold back to the farmer. ${ }^{10}$ This practice reduces the germination power of the seed and increases uncertainty as to the identity of the different varieties.

Nonetheless, despite their precarious situation and low profitability, small-scale farmers are culturally attached to cotton. They were born and have grown up with cotton and have learned to cultivate it as their

\footnotetext{
${ }^{9}$ Productive process to obtain cotton fibre from raw harvested cotton, separating the fibre from the seeds and other waste material extracted from the harvest. This is done with a ginning machine.

10 Although the cooperatives were created to improve farmers' bargaining power $v i s-a ̀$-vis large-scale buyers of cotton fibre, and also to obtain better prices through joint purchases of key inputs such as diesel, the activity of these cooperatives is currently no different from that of other intermediaries.
}

parents did; it forms part of their identity. Moreover, for them, cotton functions as a currency in a way that other crops do not: they can pick small amounts and will always find a buyer for it, albeit at a modest price.

The situation for larger scale farmers is very different. They use modern machinery and hired labour. Generally, they combine cotton production with soybeans and in some cases with sunflower, maize or sorghum. Soybeans in particular may occupy a large part of the sown area. The smaller farmers in this group are family firms, but the large-scale farmers tend to be corporations (Arza and others, 2010) whose investors are normally not involved personally with rural life. In general, these farmers have their own gin and use state-of-the-art technologies, including the full technological package associated with GM seeds (see the description in box 1). This group is the main customer of Genética Mandiyú, although they also multiply their own seeds. 
BOX 1

\section{The full technological package}

To maximize the yields and the return from its adoption, gm seeds should be accompanied by specific practices and inputs. Although it is possible to adopt just some of its components, the full technological package includes the following: gm seeds purchased in the formal market; direct sowing in a narrow rows (0.48-0.5 m wide); herbicide and insecticides to be applied throughout the crop cycle; growth regulators; defoliants and mechanical harvesting using the stripper harvester adapted to the narrow row. Use of this package requires a minimum scale to justify mechanization and technical knowledge. Funds are also needed to purchase inputs. Small-scale cotton farmers, who cannot obtain formal credit and only have their own work and that of their family to rely on, continue to sow using the conventional system ( $1 \mathrm{~m}$ wide rows) and to harvest manually. The following table estimates the yield and profitability differential between farmers who use the full technological package and those who do not:

\begin{tabular}{lcc}
\hline & $\begin{array}{c}\text { Farmers who use the full } \\
\text { technological package }\end{array}$ & $\begin{array}{c}\text { Farmers who do not use the full } \\
\text { technological package }\end{array}$ \\
\hline Yields (tons/ha) & 2.9 & 1 \\
Price of raw cotton (AR\$/ton) & 1800 & 1000 \\
Cost of seeds (AR $\$$ ha) & 630 & 80 \\
Fibre percentage & 25 & 30 \\
\hline
\end{tabular}

Source: M.G. Elena, “Costo de producción por hectárea de algodón”, National Institute for Agricultural Technology (INTA), 2010 [online] http://inta.gob.ar/documentos/costo-de-produccion-por-hectarea-de-algodon-2009-10-para-surcos-estrechos-0-52m-1/.... and workshops with farmers organized by the authors. Estimates for the 2009/2010 season.

AR\$: Argentine pesos.

Studies done by the inta Experimental Agriculture Station at Saenz Peña compare the margins obtained when different elements of the package are combined. Elena, Íbalo and Gesualdo (2006) estimate the additional benefit of sowing in a narrow row for direct sowing (sd) and conventional sowing (sc). The results show that sowing in a narrow row produces an additional benefit of $\$ 818.37$ and $\$ 553.55$ per hectare for sd and sc, respectively.

Similarly, Elena, Ybran and Lacelli (2008) analyse the costs of cotton production using different sowing and harvesting alternatives and different price scenarios. They conclude that sowing in a narrow row and using stripper harvesting has more competitive results than manual or picker harvesting and that, for the price scenario, the only profitable alternative is obtained by combining narrow row sowing and the stripper harvester.

\section{III}

\section{Repercussions of the adoption of gm cotton by farmers in the Chaco}

\section{The benefits of adopting gm seeds, according to the literature}

One of the best-known studies on the impact of adopting GM cotton in Argentina is Qaim and de Janvry (2005), which is based on surveys of a sample of cotton farmers made during the 1999-2000 and 2000-2001 agricultural seasons. At that time, users of GM cotton seeds were still few in number. The sample contains 290 observations, of which 125 correspond to farmers working areas larger than 90 ha, which then included 87 users of Bt cotton. The sample also contains observations for 173 farmers working less than 90 ha of land, none of whom were users of the technology. The authors estimate an econometric model to evaluate the extent to which the adoption of Bt cotton increased yields and reduced pesticide use 
among users. They conclude that the number of pesticide applications and the amount applied both decrease significantly when Bt seeds are sown. In addition, the technology increases yields by $500 \mathrm{~kg}$ per hectare, on average. The authors find that the yield effects are greater than those reported for other countries that have adopted the technology, such as China or the United States. The explanation for this differential effect is that pest control was deficient in Argentina prior to the introduction of the GM seed: the amount of pesticide applied with the conventional seed was less than recommended, so the adoption of Bt cotton increased yields by more than it would have done if pest control had previously been greater. ${ }^{11}$ For the same reason, and despite the fact that small-scale farmers had not adopted the Bt seed when the study was undertaken, the authors infer that the technology would be particularly effective for them, ${ }^{12}$ because the pest control normally undertaken by this group is even more deficient.

Trigo and Cap (2006) also analyse the repercussions of GM cotton in productivity and profitability terms using data from the 2001-2002 season. This study draws on the estimates published by Elena (2001) that Bt cotton raises yields by $30 \%$, to analyse the distribution of the benefits among farmers, the seed industry and the State. Based on averages, the authors conclude that $86 \%$ of the benefits are appropriated by the farmers and that the benefits received by the (single) seed firm are low, because $66 \%$ of the seed used is "white bag".

Ten years after the research done by Qaim and de Janvry (2005) and by Trigo and Cap (2006), the situation regarding the adoption of GM cotton in the Chaco is clearly different. Firstly, there are new varieties: in addition to the Bt seed there is now RR seed and the "stacked event", which are widely disseminated, mostly through informal channels. Secondly, conventional seeds have practically disappeared from the market, and it is assumed that the small amounts that do circulate are highly contaminated with transgenic material. Thirdly, boll weevil has spread and now poses the greatest threat to cotton production in the province.

Accordingly, and given that most large, medium and small-scale farmers sow GM cotton seeds, it is critically

\footnotetext{
11 Furthermore, the authors stress that this result could be underestimated, owing to the impossibility of controlling for germoplasm (genetic fund): the Bt varieties launched commercially were not specifically developed for Argentine soil, as were the conventional varieties developed by INTA and marketed until then. If this factor were controlled for, the effect attributable exclusively to the Bt gene could therefore be even be greater.

12 This study classifies farmers in the sample as large-scale if they cultivate more than 90 ha.
}

important to analyse whether their adoption by smallscale farmers has had the expected effects in terms of yield and profitability.

That is the aim of this study. Based on the conceptual framework of the socio-technical configuration of the technology, it analyses productive practices in relation to the use of GM seeds. Section III subsection 2 focuses on productive practices related to yields, while section III subsection 3 focuses on profitability. Both subsections describe breaks and continuities arising as a result of the adoption of GM technology. As there are no statistics on yields and profitability with a size breakdown, information obtained through qualitative methodologies has been used. Without generalizing, comments made by farmers and other stakeholders at the participatory workshops and interviews are used to illustrate the main arguments.

\section{Productive practices and yields}

Nowadays, GM seed is widely disseminated among small-scale farmers. Nonetheless, the seeds available to them are of dubious quality, because in all cases they are "white bag" seeds obtained informally or distributed free by the local government. ${ }^{13}$

Apart from the generalized adoption of GM seeds, small-scale farmers have not acquired machinery or changed their sowing techniques. They even continue with the practice of mono-cropping, which causes increasing deterioration of soils.

To prepare the land, they generally rely on a neighbour with a tractor to provide the service in exchange for fuel that they receive free from the government. ${ }^{14}$ If the municipality has a tractor, they use that service to prepare the land; but this is not always available because there are many farmers to share the single tractor that the municipality normally owns. ${ }^{15}$

Harvesting techniques have not changed as a result of adopting GM technology. Small-scale farmers continue to pick small amounts in each flowering, selling the raw

\footnotetext{
13 A few seasons ago, the provincial government, which historically had provided free conventional cotton seeds to small-scale farmers, delegated seed purchase to the municipalities, which obtain and distribute uncertified GM seeds.

14 "We now have 'diesel vouchers', but we have to wait for someone with a tractor to stop working in their own field and see whether they will come to the chacras in exchange for those vouchers. Not everyone wants to come to the small chacras because it is more costly and there can be problems." Small-scale farmer, Sáenz Peña.

15 "Everything takes longer for us because the municipality is responsible for ploughing the land and as there are 30 associations, they are done at random, and never reach some associations. The municipality has one tractor and is about to buy another one." Smallscale farmer, Sáenz Peña.
} 
cotton immediately because they need money to purchase basic consumer goods. ${ }^{16}$ Cotton continues to function as money for them, because in the province it can very easily be sold to warehouses or local intermediaries. Harvesting is done manually by the entire family. ${ }^{17}$ Nonetheless, since the exodus of the youth population, many families do not have enough hands at harvest time, and they need to hire harvesters, which further erodes their already low profitability.

In terms of sowing techniques, small-scale farmers from all the localities visited stated that they had not changed the distance between rows $(0.7-1 \mathrm{~m})$. When asked why they did not sow in narrow rows, farmers and INTA technical staff both explained that there were difficulties in obtaining the inputs and machinery needed to sow and harvest at that distance. ${ }^{18}$ Apart from this constraint, the workshops also identified a common perception among small-scale farmers that the yields in narrow rows are lower because the plant grows less ( "carga menos"), ${ }^{19}$ despite consensus among the INTA technicians consulted that yields are higher.

This difference between farmers' perceptions and the technical opinion exemplifies a difficulty faced by technical assistance when working with small-scale farmers. ${ }^{20}$ Moreover, it is likely that since the introduction of GM cotton, INTA technical assistance in this crop has

\footnotetext{
16 "As a family, the cotton we can pick in a week from Monday to Saturday is 2,000 or $3,000 \mathrm{~kg}$; we have to sell it immediately because we need the money for our every day lives. What we pick we sell to meet our needs. We can't pick 20 tons, it's not the same as selling $2,000 \mathrm{~kg}$." Small-scale farmer, Quitilipi.

17 "We small-scale farmers have always worked with just the family. I would sow 2 ha. When I planted vegetables, I would say: with the help from my family today I harvested the 2 ha and this is money that one makes within the family. We don't need to pay more than what the family makes from its work and that's what we live on." Smallscale farmer, Sáenz Peña.

18 "In a narrow row you need money for the technology. The defoliant ... you need size to be able to enter with the machines. They harvest by hand and at 52 years old you cannot harvest by hand". INTA agent, interviewed in September 2010.

19 "With due respect to the people at INTA, the narrow row is debatable: the calculations need to be done carefully. I spoke to people that used both methods who say that you have to make the numbers very small and it isn't clear which is best. We talk of three tons per hectare, but with a yield of $20 \%$ to $22 \%$, and I harvest with another machine or by hand and in a normal year it gives $37 \%, 38 \%, 40 \%$. So I don't know. And for the ginning, this cotton stripper charges another $\$ 100$." Small-scale farmer and member of the cooperative, Quitilipi.

20 "The government never looks out for the small farmer. No technician has ever come here to tell us what seed to use, never. The technicians are in Quitilipi, in Sáenz Peña, but no technician has ever come here to help us". Small-scale farmer, Quitilipi.

"The people at INTA give a talk here, but don't go to the chacra. Large farmers have their paid technicians, they also have INTA, they have everything." Small-scale farmer, Quitilipi.
}

decreased and is being retargeted towards other productive activities that are considered priorities for the institution.

Several reasons could explain this change in priorities. Firstly, as from 2001, the INTA extension strategy was changed from technology transfer to "technological innovation" projects, which generally pursue social, environmental, and technological needs objectives simultaneously (Alemany, 2003). In practice, these extension projects have prioritized fruit, vegetables and livestock production, ahead of industrial crops, in accordance with the principles of food sovereignty.

Secondly, INTA agents are primarily concerned with soil conditions in the region, which require urgent attention including diversification of production. Smallscale farmers are reluctant to diversify beyond cotton and food for subsistence. According to INTA technicians, this reluctance worsens the quality of soils, which in turn lowers yields. ${ }^{21}$ When asked about this, the small-scale farmers basically blamed the lack of markets to sell alternative productions, as well as extolling the virtues of cotton: it is not perishable, there is an easy market for it, and it is resistant to adverse weather conditions. ${ }^{22}$

Thirdly, it is worth stressing another aspect that affects the active role of INTA in the seeds market, relating to the privatization of knowledge. Prior to the introduction of GM crops in many developing countries, including Argentina, conventional breeding ${ }^{23}$ was done largely by the farmers themselves and public research institutions. The diffusion of GM technology and subsequent strengthening of intellectual property rights imposed a clear limit on such practices (McIntyre and others, 2008). ${ }^{24}$ As germoplasm development is a subject to economies of scale, and given that most firms producing GM seeds are global players that optimize their sales worldwide, these firms pursue active standardization strategies. Consequently, the diversity of varieties

21 "You have to consider the soil as well. This is yielding less because they have been producing cotton for 30 years. It needs crop rotation." INTA agent.

22 "I defend cotton, I'll die with cotton, because there is nothing that is as resilient as cotton, to start in this zone. If I grow 10 ha of sunflower, soya or wheat, no way, to sell I have to produce miracles: I have to register in the National Commercial Agriculture Control Office (ONCCA) $[\ldots]$ for us this is impossible. And if you grow vegetables, who would you sell to? Where is the market? If 900 farmers grow half a hectare of pumpkin each, where do we go?" Small-scale farmer, Quitilipi.

23 This refers to the conventional improvement of plants by exploiting genetic variation (either created deliberately or found in wild populations), selecting the most desirable individuals according to different agronomic characteristics.

24 In Argentina, Rossi (2006) states that the intensive propagation of GM crops has meant the privatization of knowledge production and dissemination. 
available in the market has been cut drastically, to the point where currently only three varieties are sown, and two of these come from imported gene pools. ${ }^{25}$ Before the spread of transgenics, on the other hand, the cotton seed market was dominated by the conventional varieties developed by INTA. The institution not only undertook research for the development of technological options adapted to the region and improvements and product diversification, but it also assumed responsibility for multiplication and, sometimes, the seed marketing process. In fact, until the 1990s, INTA seed production was done by "co-operating associations" (asociaciones cooperadoras) of this institution or private seed farmers that signed agreements with it under the technological linkage agreements scheme. As GM technology spread, the seed firms ended (or did not renew) their agreements with INTA, and now there is only one co-operating association producing varieties in the institution's fields, and a single seed firm that has applied for a permit to multiply INTA seeds for the 2011 season. ${ }^{26}$

In view of this, whereas in the past INTA emphasized the dissemination and correct use of its varieties, nowadays, although it remains the leading national institution undertaking cotton-specific research, ${ }^{27}$ the varieties it develops are not sold on the market. Technical assistance on the GM varieties that are used is provided mainly by private technicians, who are hired by large-scale farmers. Genética Mandiyú also provides a "technical service" and "customer service" for its customers. Small-scale farmers who cannot afford to hire private technical services and are not customers of Genética Mandiyú because they obtained their seeds on the informal market, do not generally receive technical assistance.

In brief, apart from the widespread adoption of GM cotton seeds, small-scale farmers have not changed their sowing and harvesting techniques, the machines they use have not been updated, they do not generally receive technical assistance and have not diversified their production.

25 For the 2011-2012 season, a new GM seed has been launched containing the "stacked event" on an old INTA variety (registered in 1996).

26 Interviews with INTA agents.

27 The various cotton technology research projects currently under way in INTA include a technological linkage agreement that the institution signed with the cotton-growing provinces in 2009. The aim is to generate knowledge and non-contaminating technologies for controlling boll weevil and developing integrated management. The project activities are implemented in five modules addressing the boll weevil problem, with participation from over 40 researchers and auxiliary workers from the institution. The modules range from conventional improvement of the cotton to bio-technological solutions; and there is a specific module devoted to studying intellectual property issues related to the research topic.
Not everything has stayed the same, however. Firstly, as noted above, boll weevil has become one of the key problems causing lower yields, particular for small-scale farmers who cannot afford to control the pest. The seriousness of the problem stems from the fact that it is very destructive pest given its high reproduction rate and lack of natural predators, and because it is not controlled by the $\mathrm{Bt}$ gene available in commercial seeds. Although there is a set of practices that to some extent reduce the incidence of the pest (concentrating the sowing period, shortening the plant growth cycle, destroying the stubble immediately after harvest and avoiding new shoots), these practices are not widespread among small-scale farmers. For them, the moment of sowing is determined by weather factors and by the availability of seeds; sowing in narrow rows to shorten the crop cycle requires machinery they cannot afford; immediate destruction of the stubble is not done because of a lack of fuel and because they can use it as fodder for livestock; they do not cut off new shoots because they can harvest them and obtain an extra income; and they do not apply the amount of insecticide needed to control the pest because of the cost.

Secondly, since starting to use seeds with the RR gene, most farmers have stopped hoeing ${ }^{28}$ or hiring hoes. This is highly valued by nearly all farmers, particularly as is difficult to obtain hoes. ${ }^{29}$

Thirdly, linked to the previous point, the spread of wide-spectrum herbicides is one of the main changes in productive practices arising from the introduction of GM seeds.

Fourth, there were a number of references to the problem of the rural exodus, particularly among young people. The main reasons for this exodus are problems of infrastructure and lack of opportunities. ${ }^{30}$ The exodus is causing a lack of labour which delays harvests and increases exposure to boll weevil.

In short, this subsection has shown that small-scale farmers tend to adopt an incomplete version of the GM technological package, as described in box 1 . They do not incorporate elements that represent economies of

28 Clearing the land to remove weeds.

29 "At hoeing time, the farmer has no money at all, so it is difficult to obtain hoes; this is a problem." Small-scale farmer, Villa Berthet. 30 "Family labour has decreased... they cannot harvest that area on their own and there is no labour... that means that harvesting takes longer, instead of lasting 30 days." INTA experimental station agent, September 2010.

"It also seems to me that the countryside is not providing conditions of life for young people to stay: electricity is expensive, scarce water, primary school to sixth grade, so what do you do...?" Small-scale farmer, Quitilipi. 
scale (machinery), those requiring working capital (most inputs), or better sowing practices (narrow row); nor do they control pests adequately, particularly in the case of boll weevil. They also fail to halt the deterioration of soils through crop diversification, owing to a lack of markets for alternative products to cotton. Some aspects of management of the technology previously provided by INTA are now mostly supplied by private firms or by the GM seed producing firm, which small-scale farmers cannot afford. In general, the analysis of the productive practices implemented shows that small-scale cotton farmers have not been able to improve yields by adopting GM seeds, as the literature reports for larger scale farmers.

\section{Bargaining power in the marketing chain and profitability}

The profitability of cotton production is the outcome of the cost and income equation. As there are no quantitative data available to evaluate changes in these variables following the introduction of GM seeds, the analysis is necessarily confined to an analytical argument inferred from qualitative evidence. Those tools are used to analyse the impact of the dissemination of GM seeds on costs, incomes and bargaining power (which mediate between them) among small-scale farmers.

\section{(a) Costs}

The technological package includes new inputs (mainly herbicides, but also defoliants and growth regulators), while also reducing labour costs (particularly in the hoeing process, but also in pest control) and savings on pesticides that are no longer used. As noted above, the literature assesses the balance as positive.

Given the practices of small-scale farmers, however, it is not clear that average costs have also decreased for this group. Firstly, the seeds have become more expensive even on the informal market, and they also require new inputs such as herbicide. ${ }^{31}$ Secondly, cotton production usually involves participation by the entire family, with workers being hired from outside only on exceptional basis. ${ }^{32}$ In the absence of alternative opportunities to occupy the time of discontinued family tasks, it is not

\footnotetext{
31 "Last year we ordered and bought a certain quantity of seeds, but in the end it was thrown away because people did not want to sow it because of the very high costs [...]. It's also very expensive! I'm not sure this technological package is suited to farmers working less than 50 ha." Government representative, Pampa del Indio.

32 "Transgenic seeds are very expensive and sometimes we can't buy them. So we try using the conventional seeds, which at least don't involve so much expense; we do all the work within the family." Small-scale farmer, Pampa del Indio.
}

obvious that the technology produces an economic saving for this group.

Lastly, small-scale farmers generally do not apply pesticides with conventional seeds, so they do not perceive a cost reduction in this regard.

\section{(b) Incomes}

The income received by the farmer depends on yields and the price of harvested cotton. Section III discussed the impact of the use of GM seeds on yields and concluded that it was not clear that these variables had increased for small-scale farmers as a result of using that technology. The price of harvested cotton has not been boosted by the introduction of GM, because it is set on the international market. ${ }^{33}$ Moreover, the small-scale farmer usually sells the harvested crop unprocessed, so the characteristics of the fibre, which tend to be better when picked manually than harvested mechanically, do not affect the price received. ${ }^{34}$

\section{(c) Bargaining power}

As noted above, small-scale farmers are trapped in the marketing chain, particularly by intermediaries that sell inputs to them on credit — which is paid back at high interest when the crop is sold. ${ }^{35}$ In general, they cannot choose where they buy inputs, because they have no way to pay for them and no access to the credit market. They can also not choose whom they sell to, because they are in debt to the supplier who buys the harvested crop from them. ${ }^{36}$

It can be argued that the dissemination of GM cotton has weakened and reduced the bargaining power of small-scale farmers, since they now need more inputs than before (they depend on intermediaries more than before) and because informal markets have spread.

\footnotetext{
${ }^{33}$ If anything, the opposite is probably true, given the loss of variety and diversity caused by transgenics, which could have had a negative effect on fibre quality. Nowadays, most of the cotton produced comes from imported genetic funds, which are therefore not best suited to the region's agronomic and climatic conditions.

34 The lack of payment for quality is important in the case of smallscale farmers that harvest manually. The fibre percentage of the total harvest is greater with manual harvesting (because there is less waste) than in mechanical harvesting. But by selling the cotton raw, the smallscale farmer no longer receives this differential. "Unfortunately, at the moment in our country quality is merely rhetoric; it is not paid for. Throughout our marketing system, if it can avoid paying for quality it won't pay." INTA agent interviewed in September 2010.

35 "The poison [glyphosate] costs $\$ 200$, but they charge us $\$ 600$ ". Small-scale farmer, Quitilipi.

36 "They buy from you at so much, like it or not...". Small-scale farmer, Quitilipi.

"The fact is that no matter the quality they pay you what they choose, we are their prisoners ". Small-scale farmer, Quitilipi.
} 
Although informal seed markets existed prior to the dissemination of GM seeds, small-scale farmers also had the option of buying seeds formally. ${ }^{37}$ Moreover, interaction with local seed farmers enabled them to understand the agronomic characteristics of the seed and obtain their technical advice. Conventional seeds were mostly INTA varieties, and formal seed farmers, as noted above, worked closely with the institution, which not only had obtained the technology but also took responsibility for its dissemination. Consequently, small-scale farmers were probably better informed on the varieties available, which improved their bargaining position.

Since the introduction of GM technology, the INTA role in the seed system has weakened, and the size of the formal market (both in terms of the number of formal seed producers and in the proportion of formal sales) has shrunk significantly. Although initially only largescale farmers bought GM seeds, as the informal market grew, small-scale farmers also started to adopt them.

Given this situation, in 2008 various participants in the cotton market signed a commitment to organize the seeds market (in other words, to control the multiplication of seeds and reduce the size of the informal market). Through this agreement, Genética Mandiyú authorized a number of stakeholders - typically cooperativesto purchase the original seed, multiply it, and sell it formally, ${ }^{38}$ paying for each sack obtained in the multiplication process, ${ }^{39}$ while the firm retained the right to monitor and control the multiplication process. Since then, the Genética Mandiyú share of the seeds market has grown from $8 \%$ in 2008 to $16 \%$ in $2009 .{ }^{40}$

Nonetheless, although it is clear that informal markets undermine the bargaining power of small-scale farmers, by restricting their access to information and thus reducing their autonomy; it is also clear that not all attempts at formalization benefit them. The aims in formalizing the seed market can also harm the small-scale farmer if the price of access to the technology increases by too much, or if the intermediaries consolidate their

\footnotetext{
37 This refers to the possibility of buying from one of the various authorized multipliers of INTA varieties. With time, as GM seeds were disseminated, access to conventional seeds in the formal market came to depend on the location of the farmers, such that those closest to the INTA experimental fields had best access. (Interview with INTA agent).

38 The provincial government finances cooperatives to purchase the original seed.

39 According to information from Genética Mandiyú, the price of a sack of original seeds of the "stacked" event was about \$200. The payment was around $\$ 45$ per sack multiplied, including the de-linting service (the process in which the seed is cleaned, removing the linter or fluff and making it more effective for sowing) by Genética Mandiyú.

40 Interview with industry representative.
}

bargaining power in the chain by becoming "authorized" intermediaries.

In short, the introduction of GM seeds has made small-scale farmers more vulnerable as input purchasers; they have to obtain a larger variety of inputs and can only do so on the informal market. It is not yet clear how recent attempts to formalize the seed market will affect small-scale farmers. Some risks could decrease (those related to access to information), and, if seed quality improved, their yields could also increase. On the other hand, small-scale farmers will face higher costs and, given that the number of intermediaries could decline, their already-scarce bargaining power with input suppliers could deteriorate. The importance of asymmetric bargaining power to the detriment of small-scale farmers within the marketing chain is illustrated by the fact that one of this sector's main demands is for a floor price to be set to improve their bargaining position. ${ }^{41}$

The situation of large-scale farmers is clearly different and, as has been discussed in the literature, the adoption of GM technology has brought them visible benefits. Firstly, it enables them to significantly save on labour costs, by improving the treatment of weeds, and also to economize on pesticides, which are no longer needed owing to the use of the Bt seed (Qaim and de Janvry, 2005) —although the spread of the boll weevil pest detracts from this claim. Secondly, introduction of the GM package has made it possible to extend the agricultural frontier, turning soybeans into a suitable crop for the region.

Overall, while GM technology has brought higher yields and profitability to large-scale farmers, the profitability gap between them and small-scale farmers has widened as the latter have not experienced significant improvements.

The larger profitability gap is illustrated by the pressure exerted on small-scale farmers to sell their land. Although there are no official figures on farm concentration trends (the most recent data come from the 2002 agricultural census), nor on the exodus from rural areas (the most recent information corresponds to the 2001 population census), ${ }^{42}$ there is a widespread

\footnotetext{
41 "If there is a minimum wage for the rural worker, why isn't there a floor price for the farmer?" Small-scale farmer, Quitilipi. "The government should fight to guarantee prices." Small-scale farmer, Quitilipi.

42 The most recent data for the Chaco show that the number of farms decreased by $21 \%$ between 1988 and 2002 . Moreover, while the rural population in the province amounted to $53 \%$ in 1970 , it only represented $17 \%$ in 2001.
} 
perception among small-scale farmers, ${ }^{43}$ INTA agents and government representatives ${ }^{44}$ that a phenomenon of this type is unfolding. Moreover, the issue of land sales and concentration has been reported by various farmers' organizations ${ }^{45}$ and mentioned in academic studies. ${ }^{46}$

Lastly, the widening profitability gap may have consolidated a discourse claiming that cotton cannot be profitable for small-scale farmers. For example, the provincial government and certain INTA officials argue that small-scale farmers should abandon cotton production

\footnotetext{
43 "There is no alternative, if there is no technology in 10 years we'll disappear, we'll no longer exist. Ten years ago there were 32,000 inhabitants: 17,000 in the countryside and 15,000 in the town. Now we are 42,000 inhabitants and have 31,000 in the town and 11,000 in the countryside [...] we are existing: Me, by being stubborn , because I like the cotton and I defend cotton." Small-scale farmer and cooperative representative, Quitilipi.

44 "It used to be said that cotton was a 'social crop' because it employed a lot of labour, but not any more." Government representative, Pampa del Indio.

45 Various social movements have expressed their concern about this situation, such as the Multisector Forum for Chaco Lands (foroporlatierrachaco.blogspot.com/). See the journalistic article by Aranda, 2011.

46 The concentration of land in the hands of large-scale owners or corporations has been a key phenomenon since the 1990s (see, for example, Rossi, 2006 and Manzanal, 2009). See also the book by Valenzuela and Scavo (2009), which describes the resistance by small-scale farmers to the concentration that has resulted from the expansion of the agricultural business model in the Chaco. Other authors, in contrast, claim that concentration, although considerable, reflects a global process of intensification of production under the productivist paradigm (Trigo and Cap, 2006).
}

\section{IV}

\section{Conclusions}

While transgenic crops have expanded rapidly over the last decade, their benefits are not distributed uniformly among all farmers. This article has analysed the changes in yields and profitability caused by the adoption of GM cotton by small-scale farmers in Chaco province.

Throughout the article, it has been argued that the benefits of adopting the technology depend on multiple aspects that go beyond the virtues of the technological artifact itself, in this case GM seed. If the technology is seen as a socio-technical configuration, the expected benefits will depend on the context in which it is adopted, which needs to be analysed from different points of view.

Nonetheless, the literature describing the repercussions of GM cotton in Argentina has not and turn to alternative crops (generally vegetables), which are less scale-dependent, better suited to degraded soil conditions, more related to food sovereignty, and potentially more profitable. ${ }^{47}$

Most small-scale farmers disagree with these views, however. As noted above, not only do they have a cultural link to cotton, but it is hard for them to find markets for alternative products, whereas with cotton there is at least an organized marketing chain. Accordingly, small-scale farmer organizations do not generally advocate abandoning the crop; their main claims relate to avoiding land sales and the rural exodus, and finding ways to increase their bargaining power to improve profitability, including setting a floor price. ${ }^{48}$

\footnotetext{
47 "Cotton is no longer profitable for some of the farmers we spoke to. We need to see this group as food producers. Paradoxically, Chaco province imports $83 \%$ of the agricultural production it consumes, and the small-farmers, the most deprived and abandoned sector, are in the best position to produce food." Government representative, Pampa del Indio.

"I used to be a cotton fanatic, but now I doubt that it is useful for small-scale farmers. There may be more profitable alternatives such as vegetables." INTA experimental station agent, interviewed in September 2010.

"My conscience is clear if I create productive alternatives. If I go and tell my people: "Don't grow cotton" [...] but we are encouraging some people not to grow cotton because it is not in their interests! Because they don't have the right soil, because they don't have access to the machinery. It's not in the minifundista's interest." INTA experimental station agent.

48 Interview with representatives of the Association of Small-Scale Farmers of the Chaco (appch) Pampa del Indio.
}

considered the different contexts in which GM seeds have been adopted. The existing evaluations tend to standardize the constraints faced and the behaviours of the different types of farmers; so they tend to generalize the conclusions to all types of farmers.

This article has analysed the socio-technical configuration of small-scale cotton growers in the Chaco, particularly in terms of productive practices that affect the yields and profitability of cotton production, with the aim of identifying continuities and breaks associated with the introduction of GM seeds.

The main argument developed in this article is that the constraints faced by small-scale farmers in improving their yields and profitability in cotton production remained 
in place, and even were exacerbated, following the adoption of the GM technology. As the literature reports higher profitability for large-scale farmers as a result of adopting this technology, the profitability gap between large and small scale farmers must have widened.

A significant difference between these two types of farmers is that small farmers adopt an incomplete version of the technological package. As they do not have access to formal credit to finance working capital, and they produce on a small-scale, their production does not include all of the inputs of the package, and processes continue to be done manually.

Deficient pest management practices have serious consequences, since boll weevil, which is not controlled by the GM technology, has become a real threat to cotton growing in Argentina. Small-scale farmers are particularly affected by the pest, because usually they cannot afford to follow the recommended practices.

In short, the productive practices of small-scale farmers fall short of what is needed to obtain the best yields from GM seeds (because they do not adopt the full package). Besides, they now receive less technical assistance for cotton production than before. Consequently, it is not clear that their yields have increased as a result of adopting the technology.

Apart from yields, profitability also depends on relative input and production prices. The qualitative evidence suggests that costs have not fallen significantly for this group, because they did not hire labour or use pesticides (at least not systematically) before the introduction of GM seeds. In terms of the cotton price, as quality did not improve following the introduction of the new technology, it cannot be concluded that incomes are higher for this reason.

In any event, the real price faced by the smallscale farmer depends, largely, on its capacity to bargain within the production chain. As noted above, small-scale farmers have traditionally been trapped in this chain: they generally pay higher prices for their inputs and receive lower prices for their output. The analysis of this article shows that the dissemination of GM cotton has weakened the bargaining capacity of small-scale farmers: firstly, because they depend on more inputs than before; and secondly because the expansion of informal markets reduces the options available and worsens access to information (for example, only GM seeds of dubious identity are sold). With their bargaining power weakened, their chances of improving profitability are also reduced.

As the adoption of this technology did bring clear increases in profitability for large-scale farmers (as reported in the existing literature), the profitability gap between them and small farmers must have widened.

This situation is illustrated by: (i) discourses circulating among policymakers that suggest smallscale farmers should abandon cotton production; (ii) the conclusions of several researchers regarding the increased concentration of land ownership; (iii) the widespread perception among farmers of the rural exodus phenomenon; and (iv) complaints made by peasant organizations of the pressures put on them to sell their land.

The question now is whether there are alternative ways to reduce this gap by improving the yields and profitability obtained by smaller farmers.

We believe the GM technologies have been widely accepted because they do not call into question the dominant agricultural paradigm, based on the intensification of production and increasing scale. Under this "productivist" paradigm, the profitability gap is likely to continue widening, and the sustainability of production by small-scale cotton farmers will remain at risk. Nonetheless, alternative paradigms have recently been supported by the international literature. In particular, the agro-ecological paradigm advocates conservation of natural resources such as water and soil and biodiversity (McIntyre and others, 2008; Vanloqueren and Baret, 2009); and a different accumulation strategy is proposed, based on autonomous input supply and sustainable resource management. Argentina has an example of agro-ecological cotton production (Cooperativa Agroecológica del Litoral, located in San Martín), but there are few farmers currently participating. For a farmer to switch to agro-ecological production, it needs to radically change productive practices and be willing to absorb economic losses during the transition period. These disadvantages could explain why agro-ecology has not been adopted by small-scale farmers as quickly as GM technology (which does not question the farmers' habitual practices).

Policies to improve the situation of small-scale farmers can also be envisaged under the current production system. In fact, this article has identified several policies and strategies that are currently being implemented, which could improve their situation:

- The Chaco provincial government has recently set up "rural service consortia" with potential to empower small-scale farmer organizations. Although many of these are not yet fully functioning and they have not received the provincial funds promised to them, when this happens their members should be able to act collectively in the market, both in purchasing 
inputs and in selling their output. This would increase their bargaining power in the marketing chain, which is one of the major obstacles to raising their profitability.

- The Agricultural Single Social Tax (Monotributo Social Agropecuario) policy creates a special national tax regime for small-scale farmers, enabling them to be legally registered at no cost. This tool has the potential to expand alternatives for selling the harvested crop, thereby improving the prices they can obtain. Nonetheless, the coverage of this system is still limited. Specific actions are needed to streamline administrative process and disseminate the initiative to expand coverage and build trust.

- INTA has developed a narrow-row harvester which, given its size, is suitable for small-scale farmers. Although this machine is not yet available in the Chaco, INTA has signed agreements with metallurgy firms to produce it for the national market.

- INTA is promoting and contributing to the organization of "free trade fairs", where small-scale farmers can sell their produce for family consumption (for example, jellies, jams, and other items). The main advantage of these initiatives is that they eliminate intermediaries and promote crop diversification. Nonetheless, the number of participants in each fair is limited, which excludes a large number of farmers. Secondly, in many locations, the fair has little chance of generating sufficient demand, because the public mostly consists of small-scale farmers who self-supply. Consequently, this type of production needs to be incorporated into other marketing channels, such as the central markets of the main cities.

- Since 2009, an INTA research project, financed by cotton-producing provinces, has been attacking the problem of boll weevil on several fronts (ranging from biotechnology to conventional improvement, and including bio-insecticides). As INTA is well aware of the situation of small-scale farmers, the results of this research could produce practical benefits for small-scale production.

Much still remains to be done to improve the profitability of small-scale cotton growers in the Chaco. The following paragraphs outline a number of policies that could be implemented without a radical change in the productive paradigm:

- Improve technical assistance for small-scale cotton growers. There are a number of production techniques that could be adapted to the requirements of small-scale farmers (for example direct sowing and narrow rows). INTA has experience of working with these groups and has a major role to play in the process.

- Create financial schemes for small-scale farmers. These should take account of the fragile property rights of this group and be designed for the acquisition of machinery and financing for working capital. In particular, such schemes could usefully be organized in conjunction with the development of consortia to allow collective borrowing.

- Guarantee access to good-quality GM seeds for small-scale farmers, either by exempting them from the payment of royalties, or else authorizing consortia or other farmer organizations to multiply seeds (in other words, broadening the scope of the existing agreement).

- Actively control expansion of the boll-weevil pest in zones that are not yet infested, and help smallscale farmers to control it. These activities should be promoted by the provincial government and by the National Food Health and Quality Service (SENASA), which for 10 years has been running a boll-weevil prevention and eradication programme, in coordination with neighbouring countries that are also affected (Brazil and Paraguay).

(Original: Spanish) 


\section{Bibliography}

Alemany, C. (2003), "Apuntes para la construcción de los períodos históricos de la extensión rural del INTA", La extensión rural en debate: Concepciones, retrospectivas, cambios y estrategias para el mercosur, Buenos Aires, National Institute for Agricultural Technology (INTA).

Aranda, D. (2011), "La reforma agraria, al revés: De Menem a Kirchner, 15 años de soja”, mu, No. 43, Buenos Aires, La Vaca.

Arza, V. and others (2010), "Problemas de la regulación en semillas: El caso del algodón transgénico en el Chaco", Desarrollo económico, vol. 49, No. 196, Buenos Aires, Institute of Economic and Social Development (IDES).

Becerra, N., C. Baldatti and R. Pedace (1997), Un análisis sistémico de políticas tecnológicas. Estudio de caso: El agro pampeano argentino, 1943-1990, Buenos Aires, Centre for Advanced Studies, University of Buenos Aires.

Bijker, W.E. (1995), Of Bicycles, Bakelites, and Bulbs: Toward a Theory of Sociotechnical Change, Cambridge, Massachusetts, MIT Press.

Elena, M.G. (2010), "Costo de producción por hectárea de algodón”, National Institute for Agricultural Technology (INTA) [online] http://inta.gob.ar/documentos/costo-de-produccion-porhectarea-de-algodon-2009-10-para-surcos-estrechos-0-52m-1/. (2001), "Ventajas económicas del algodón transgénico en Argentina", Documento de trabajo, Estación Experimental Sáenz Peña, National Institute for Agricultural Technology (INTA).

Elena, G., S. Íbalo and E. Gesualdo (2006), "Evaluación económica de prácticas de manejo de algodón”, Chaco, EEA Saénz Peña.

Elena, G., R. Ybran and G. Lacelli (2008), "Evaluación económica de alternativas de sistemas de siembra y cosecha de algodón en las localidades de Santa Fe y Chaco", National Institute for Agricultural Technology (INTA).

Gárgano, Cecilia (2011), "La reorganización de las agendas de investigación y extensión del Instituto Nacional de Tecnología Agropecuaria (INTA) durante la última dictadura militar argentina (1976-1983)", Realidad económica, No. 258, Buenos Aires, Instituto Argentino para el Desarrollo Económico (IADE).

Grossi-de-Sa, M.F. and others (2007), "Susceptibility of Anthonomus grandis (cotton boll weevil) and Spodoptera frugiperda (fall armyworm) to a crylia-type toxin from a Brazilian Bacillus thuringiensis strain", Journal of Biochemistry and Molecular Biology, vol. 40, No. 5.

ICAC (International Cotton Advisory Committee) (2009), "Biotech cotton and the technology fee", icac Recorder, vol. 27, No. 1.

Klein, H.K. and D.L. Kleinman (2002), "The social construction of technology: structural considerations", Science, Technology \& Human Values, vol. 27, No. 1, Sage Publications.

Kleinman, D.L. (1995), Politics on the Endless Frontier: Postwar Research Policy in the United States, Durham, Duke University Press.

Lanteri, A., V. Confalonieri and M.A. Scataglini (2003), "El picudo del algodonero en la Argentina: Principales resultados e implicancias de los estudios moleculares", Revista de la Sociedad Entomológica Argentina, vol. 62, No. 3-4, Mendoza, Sociedad Entomológica Argentina.

Manzanal, M. (2009), "El desarrollo rural en Argentina. Una perspectiva crítica", Desenvolvimento rural no Cone Sul/ Desarrollo rural en el Cono Sur, J. Almeida and J.A. Dessimon Machado (orgs.), Porto Alegre, Associação Holos Meio Ambiente e Desenvolvimento.

McIntyre, B.D. and others (eds.) (2008), International Assessment of Agricultural Knowledge, Science and Technology for Development (iaastd): Global Report, Island Press.

Pinch, T. (1996), "The social construction of technology: a review", Technological Change: Methods and Themes in the History of Technology, vol. 35, Harwood Academic Publishers.

Pinch, T. and W.E. Bijker (1987), "The social construction of facts and artifacts", The Social Construction of Technological Systems, W. Bijker, T. Hughes and T. Pinch (eds.), Cambridge, Massachusetts, Massachusetts Institute of Technology.

Qaim, M. and A. de Janvry (2005), "Bt cotton and pesticide use in Argentina: economic and environmental effects", Environment and Development Economics, vol. 10, No. 02, Cambridge University Press.

(2003), "Genetically modified crops, corporate pricing strategies, and farmers' adoption: the case of Bt cotton in Argentina", American Journal of Agricultural Economics, vol. 85, No. 4, Milwaukee, Agricultural \& Applied Economics Association.

Rosen, P. (1993), "The social construction of mountain bikes: technology and postmodernity in the cycle industry", Social Studies of Science, vol. 23, No. 3, Sage Publications.

Rossi, D.O. (2006), "El contexto del proceso de adopción de cultivares transgénicos en la Argentina", Agromensajes, vol. 20, No. 16-27, Rosario, Facultad de Ciencias Agrarias.

Trigo, E. and E. Cap (2006), "Diez años de cultivos genéticamente modificados en la agricultura argentina", ArgenBio, unpublished.

Trigo, E. and others (2002), Los transgénicos en la agricultura argentina: Una historia con final abierto, Buenos Aires, Libros del Zorzal.

Trigo, E., J. Falck-Zepeda and C. Falconi (2010), Biotecnología agropecuaria para el desarrollo en América Latina: Oportunidades y retos, Washington, D.C., Inter-American Development Bank (IDB)

Valenzuela, C. and A. Scavo (2009), La trama territorial del algodón en el Chaco: Un enfoque multiescalar de espacios en transición, Buenos Aires, Editorial La Colmena.

Vanloqueren, G. and P.V. Baret (2009), "How agricultural research systems shape a technological regime that develops genetic engineering but locks out agroecological innovations", Research Policy, vol. 38, No. 6, Amsterdam, Elsevier.

Williams, R. and D. Edge (1996), "The social shaping of technology", Research Policy, vol. 25, No. 6, Amsterdam, Elsevier. 